\title{
Batismo e compadrio escravo no Sul de Mato Grosso (1836-1862)
}

\author{
Divino Marcos de Sena ${ }^{1 *}$ \\ ${ }^{1}$ Universidade Federal de Mato Grosso do Sul, Corumbá/MS - Brasil
}

\section{RESUMO}

No século XIX, as relaçóes de compadrio instituídas pela Igreja Católica e formalizadas pelo batismo favoreciam a união entre indivíduos e famílias. Além do sentido relacional, os escravos da freguesia de Nossa Senhora da Conceição de Albuquerque utilizaram-se estrategicamente desse sacramento. De acordo com a documentação paroquial, o batismo poderia servir para atingir objetivos que variavam de escravizado para escravizado e conforme os padrinhos escolhidos para os seus filhos. Este artigo discute as relações construídas ou intensificadas por escravos dessa freguesia, pertencente à província de Mato Grosso, Império do Brasil, mas em fronteira litigiosa, no período anterior à sua ocupação pelas tropas de Solano Lopez, durante a Guerra do Paraguai contra a Tríplice Aliança.

Palavras-chave: batismo; escravidão; estratégias; freguesia de Albuquerque; século XIX.

\section{Baptism, slavery and godparentship in the South of Mato Grosso (1836-1862)}

\section{ABSTRACT}

Throughout the $19^{\text {th }}$ century, godparentship relations instituted by the Catholic Church and formalized through baptism strengthened the connection between individuals and families. Besides the relational meaning, the slaves of the Parish of Nossa Senhora da Conceição de Albuquerque used this sacrament strategically. According to the parish documents, baptism could be used to achieve goals that varied among slaves, and depended on the godparents they chose for their children. This paper discusses the relationships built or intensified by slaves in the Parish, which belonged to the province of Mato Grosso, in the Brazilian Empire,

DOI: http://dx.doi.org/10.1590/2237-101X02104307.

Artigo recebido em 23 de outubro de 2018 e aceito para publicação em 16 de abril de 2019.

* Professor da Universidade Federal de Mato Grosso do Sul / Curso de História, campus do Pantanal, Corumbá/MS - Brasil. E-mail: divinosena@yahoo.com.br. ORCID: https://orcid.org/0000-0002-3023-1120. 
during a border dispute, in the period prior to its occupation by the troops of Solano Lopez, during the Paraguayan War against the Triple Alliance.

Keywords: baptism; slavery; strategies; Albuquerque parish; $19^{\text {th }}$ Century.

\section{Bautismo y compadrazgo esclavo en el Sur de Mato Grosso (1836-1862)}

\section{RESUMEN}

En el siglo XIX, las relaciones de compadrazgo establecidas por la Iglesia Católica y formalizadas por el bautismo favorecían la unión entre individuos y familias. Además en el sentido de relacionamiento, los esclavos de la feligresía de Nuestra Señora de la Concepción de Albuquerque utilizaron estratégicamente de éste sacramento. De acuerdo con la documentación parroquial, el bautismo podría servir para atender objetivos que variaban de esclavizado para esclavizado y conforme a los padrinos escogidos para sus hijos. Este artículo discute las relaciones construidas o intensificadas por los esclavos de esa feligresía perteneciente a la provincia de Mato Grosso, Imperio del Brasil, pero en la frontera en litigio, en el periodo anterior a su ocupación por las tropas de Solano López, durante la Guerra del Paraguay con la Triple Alianza.

Palabras clave: bautismo; esclavitud; estrategias; Feligresía de Albuquerque; siglo XIX.

O território do atual estado de Mato Grosso do Sul possui uma população bastante heterogênea. Além dos indígenas, indivíduos de diferentes procedências, em variados períodos, engrossaram o número de habitantes, ampliando a complexidade nas características físicas, nas formas de organização, nas práticas, nos costumes etc. Entre eles, africanos e afrodescendentes foram inseridos como escravizados durante o Oitocentos, quando começou, de forma mais significativa que na centúria anterior, a ocupação não indígena na região.

O município de Corumbá, na fronteira entre o Brasil e a Bolívia, no estado de Mato Grosso do Sul - durante o Império pertencente à província de Mato Grosso ${ }^{1}$ - tem sido recorte espacial de pesquisas acadêmicas nos últimos 50 anos (BENFICA, 2016; SENA, 2017a). No conjunto de trabalhos, um reduzido número abordou a presença e a participação escrava na formação da sociedade na área que, desde o final do século XVIII, foi ocupada por colonos portugueses.

\footnotetext{
${ }^{1}$ Em 1977, o estado de Mato Grosso foi fragmentado para a criação do estado de Mato Grosso do Sul.
} 
Mapa 1 - Mato Grosso do Sul (Divisão político-administrativa). Destaque para o Município de Corumbá

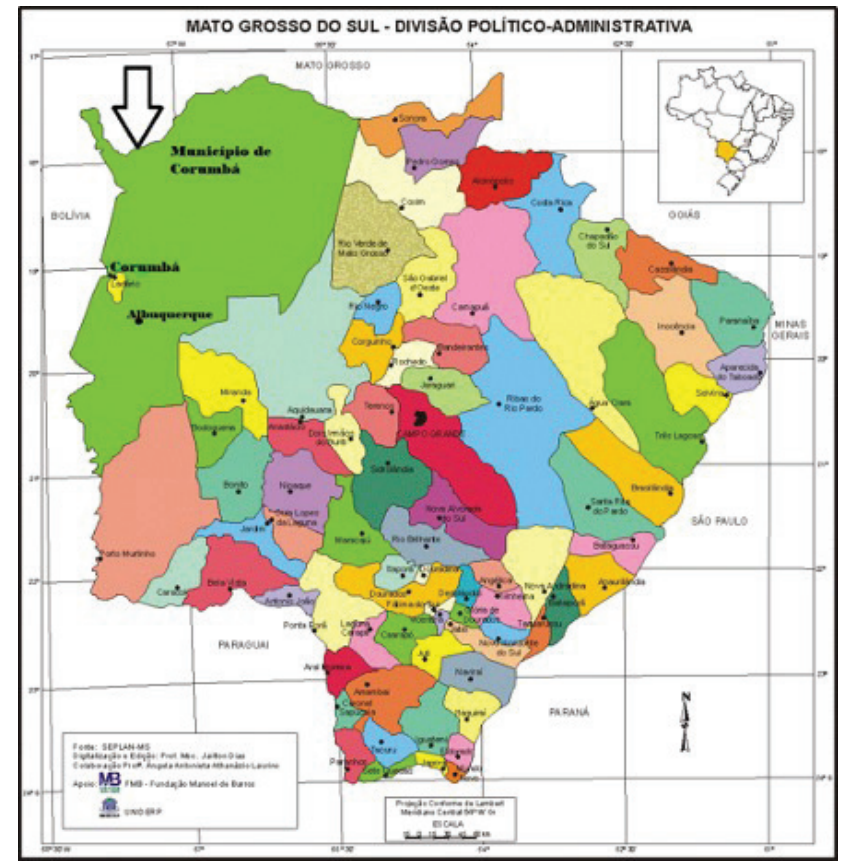

Fonte: Secretaria de Planejamento e Coordenação Geral de Mato Grosso do Sul (SEPLAN-MS). Digitalização e edição: Prof. Jailton Dias.

Os estudos existentes privilegiaram principalmente os escravos na dinâmica de trabalho, as formas de violência que eles sofreram e as resistências que empreenderam para fugir das práticas de repressão. ${ }^{2}$ Alguns pontos dessas abordagens estão vinculados a uma vertente comum em produçôes sobre o tema até os anos 1980 (sob a influência teórico-metodológica do materialismo histórico) e hoje criticados em vários aspectos (QUEIROZ, 2005; FARIA, 1998).

As formas de sociabilidade, vivências cotidianas, estratégias e outras expressóes do comportamento de escravizados na regiáo em destaque são temas que ainda merecem maior atenção de historiadores. ${ }^{3}$ Lacunas permanecem diante da dispersão ou da ausência de fontes que propiciem análises mais amplas e profundas, como uma descrição microanalítica, por exemplo.

Há carência de investigaçóes como as produzidas recentemente sobre os escravizados de outras espacialidades que compóem o território brasileiro. Entre as abordagens, estão as que remetem às estratégias de apadrinhamento e compadrio, ou seja, o uso consciente e tático de uma celebração católica por escravizados. Visando a contribuir com a discussão sobre o tema, este artigo analisa o batismo e as relaçóes de compadrio estabelecidas por escravos na freguesia de Albuquerque.

\footnotetext{
${ }^{2}$ Nessa perspectiva de análise, conferir: BRAZIL, 2002; ALMEIDA, 2008; MOURA, 2008.

${ }^{3} \mathrm{Um}$ dos poucos estudos a esse respeito é MAIA, 2014.
} 


\section{Uma freguesia no Pantanal e em fronteira litigiosa}

A freguesia de Nossa Senhora da Conceição de Albuquerque foi uma das primeiras a serem criadas na fronteira sul da província de Mato Grosso com a Bolívia, em pleno Pantanal, pela Lei Provincial de 26 de agosto de 1835. Sua sede foi instalada em Albuquerque e a ela ficaram filiadas as capelas do Presídio de Coimbra e da Povoação de Albuquerque (Corumbá).

Antes de ser elevada à categoria de freguesia, Albuquerque teve uma historicidade ligada às estratégias da Coroa Portuguesa, que intencionava garantir territórios no contexto de disputa com a Espanha, no final do século XVIII. Nas décadas seguintes à sua fundação, ela abrigou uma Fazenda Pública de gado e, em 1819, recebeu a Missão Capuchinha de Nossa Senhora da Misericórdia. Indígenas das etnias Guaná e Kinikinau foram aldeados em missóes próximas à sede da freguesia (SILVA, 2001). De 1827 até os anos 1850, Albuquerque sediou o Comando Geral da Fronteira do Paraguai, com a presença de alguns militares direcionados para a administração e a fiscalização do território. $\mathrm{O}$ crescimento no período motivou a sua escolha como sede de freguesia. Sua posição, à margem direita do rio Paraguai, perto da foz do rio Miranda, facilitava a comunicaçáo com o Forte de Coimbra, as povoaçôes de "Albuquerque Velha" (Corumbá), Miranda, Camapuã e instalaçôes rurais.

Rodeada por aldeias próximas, a sede era frequentada ou mesmo habitada por indígenas das etnias Chamacoco, Guaná, Cadiwéu, Caiuá, Kinikinau, Guaicurú, Guató e Laiana. A população era pequena, assim como a densidade demográfica da província de Mato Grosso no mesmo período (SENA, 2013). Os dados demográficos indicam modificaçóes a partir de meados do oitocentos. Em 1839, por exemplo, a população foi contabilizada em 468 (37 escravos e 431 livres), enquanto que uma década depois estava em 1.894 (55 escravos e 1.839 livres ${ }^{4}$ ), um crescimento de mais de $400 \%$ no total da população, de $426 \%$ para os livres e de $48 \%$ para os escravos (FALA DO PRESIDENTE, 1839, p. 87; RELATÓRIO DO PRESIDENTE, 1849, p. 31). O aumento populacional pode ser relacionado às mudanças que aconteceram naquela faixa de fronteira litigiosa e incerta 5 , mas já com a presença de pessoas que falavam o português e de autoridades brasileiras. Depois de 1830, a criaçáo bovina cresceu e foi favorecida, entre outros fatores, pelas condiçôes do terreno e pela instalação de famílias provenientes de outras localidades de Mato Grosso, que formaram propriedades rurais no Pantanal (ESSELIN, 2011). Os moradores viviam basicamente de serviços ligados à pecuária e à pequena agricultura.

\footnotetext{
${ }^{4}$ Não é possível afirmar se nesse total estão contabilizadas as diversas etnias indígenas que habitavam a área da freguesia. É provável que nele estivessem aquelas situadas mais próximas à sede da freguesia. Contudo, nos livros de batismos, os indígenas aparecem relacionados na seçáo de livres, juntamente com brancos, mestiços e afrodescendentes.

${ }^{5}$ As fronteiras geopolíticas entre os países recém-independentes politicamente das metrópoles ibéricas não estavam definidas. As disputas referentes aos limites territoriais foram um dos pontos que colaboraram para a eclosão da Guerra do Paraguai contra a Tríplice Aliança (1864-1870) (DORATIOTO, 2002).
} 
A fronteira sul da província foi igualmente atingida pelas consequências da abertura da navegação a vapor nos rios Paraguai e Paraná, pelo Tratado de Amizade, Comércio e Navegação, entre o Império do Brasil e a República do Paraguai, em 6 de abril de 1856. Corumbá, situada a $70 \mathrm{~km}$ de distância de Albuquerque, ficou como porto limite para a circulação de navios estrangeiros e de maior calado, e ocupou a posição de entreposto comercial da província. Essas transformaçôes favoreceram o aumento populacional, que foi interrompido com o início da Guerra do Paraguai contra a Tríplice Aliança (1864-1870), quando as forças de Solano Lopez atacaram e ocuparam a região (CORRÊA, 1981).

Mapa 2 - Parte sul da província de Mato Grosso com localização de Albuquerque e Corumbá (1860)

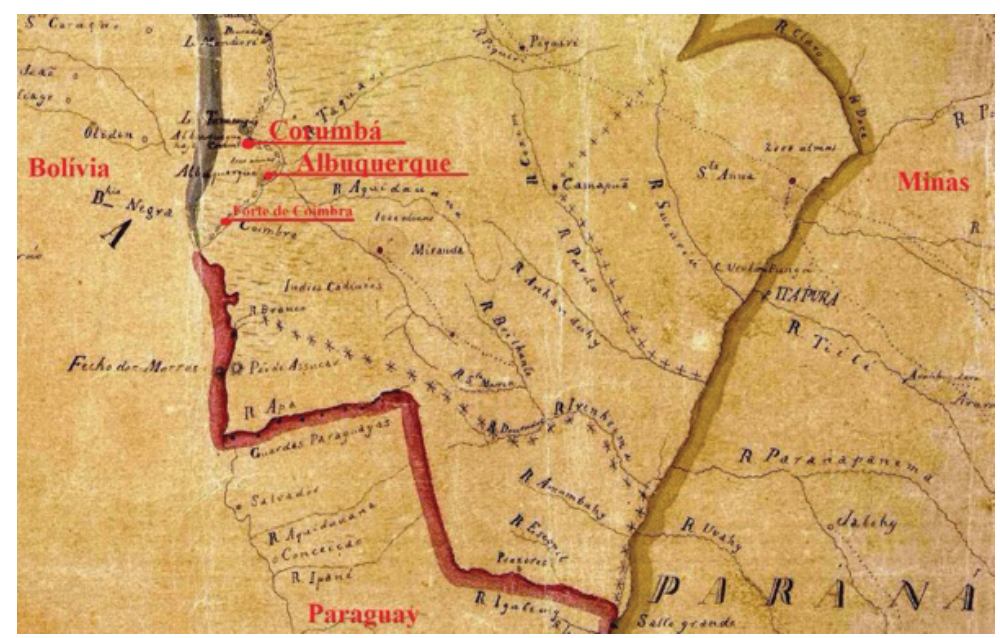

Fonte: MELGAÇO, 1860. 1 mapa ms., Entelado, 42,5 x 54,5cm em f. 55,8 x 74,5 cm. Disponível em: <http://objdigital.bn.br/objdigital2/acervo_digital/div_cartografia/cart542749/cart542749.html>. Acesso em: 30 mar. 2017.

Obs.: O mapa original foi recortado para focalizar o Sul de Mato Grosso e adaptado com alteraçôes em grafia vermelha para indicar as localidades fronteiriças, o Forte de Coimbra e a sede da freguesia de Albuquerque e da povoação de Corumbá.

A quantidade de escravos africanos e afrodescendentes, além de reduzida, teve crescimento menor que a de livres. Não existiu, na freguesia, número elevado de escravizados para a realizaçáo de atividades manuais ligadas ao trato com o gado e à lavoura. Indígenas e outros livres pobres ${ }^{6}$ foram aproveitados nessas atividades, visto que eram contratados como camaradas ou "incluídos" como agregados(as) aos domínios dos proprietários da região (SENA,

\footnotetext{
${ }^{6}$ No conjunto da população, os livres pobres eram aqueles que não integravam as chamadas famílias tradicionais, ocupantes de cargos públicos, que possuíam prestígio econômico, político e social. Em Mato Grosso, os livres pobres eram "pessoas brancas (portugueses e brasileiros não índios), negros livres; indígenas e seus respectivos descendentes; mestiços, denominados cabras, mulatos, crioulos, caborés, pardos etc. Moravam nos ambientes rurais, urbanos e militares; eram mulheres, homens, crianças etc." (SENA, 2013, p. 19-20).
} 
2010, p. 153-173). Essa característica náo bloqueou a presença de cativos de diferentes procedências e misturas, com suas estratégias de sobrevivência, formas de sociabilidade e de ajuda mútua surgidas nas vivências cotidianas e no interior das redes de sociabilidade. Entre as ações dos escravizados, os batismos de seus filhos foram utilizados com fins específicos e nem sempre restritos aos princípios do sagrado e do secular, porque portavam aspectos pertencentes à lógica de funcionamento do sistema escravista.

\section{Os batismos}

As relaçóes de compadrio instituídas pela Igreja Católica, normatizadas a partir do Concílio de Trento (1545-1563) e reforçadas pelas Constituiçóes Primeiras do Arcebispado da Bahia (1707), vigentes até o final do século XIX, eram formalizadas pelo batismo. O primeiro de todos os sacramentos oferecia ao pagão o ingresso ao Cristianismo e aos demais sacramentos (crisma, matrimônio etc.) e a remissáo do pecado original. $\mathrm{O}$ batizando era aceito como filho de Deus e feito herdeiro da glória e do reino do céu, com salvaçáo, caso não cometesse, antes da morte, algum pecado mortal.

Os padrinhos ficavam encarregados da permanência do afilhado na fé; como seus pais espirituais, teriam obrigação de lhe ensinar a doutrina cristã e os bons costumes (CONSTITUIÇÓES, 2011, Título XVIII, p. 26). O batismo evidenciava, como formador de parentesco espiritual, relaçóes de compadrio que envolviam pais carnais e pais espirituais, e de apadrinhamento, entre afilhado e padrinhos.

No século XIX, os batismos propiciavam a união entre famílias e indivíduos. Compadre, em dicionários oitocentistas, era "o padrinho do filho, o qual referindo-se aos pais, é compadre do pai e da mãe" e "estar compadre de alguém, era estar em boa amizade". O parentesco de compadres era chamado de compadrado (PINTO, 1832, p. 260). Diferentemente do parentesco consanguíneo, o batismo era decorrente de uma escolha. Geralmente, os pais ou responsáveis dos batizandos selecionavam os padrinhos. Por significar um "renascimento espiritual", os batizandos tinham com os padrinhos um novo vínculo filial. O batismo "implicava a constituição de laços com uma nova família espiritual, que influenciava diretamente a carnal" (VENÂNCIO; SOUSA; PEREIRA, 2006, p. 276). A partir dele, o compadrio era produzido "na Igreja entre indivíduos que o carregavam para fora da instituição formal" e projetavam "para dentro do ambiente social” (GUDEMAN e SCHWARTZ, 1988, p. 37).

Além do sentido espiritual pautado nos critérios católicos e relacionais, os batismos eram prática adotada com fins específicos, nos séculos XVIII e XIX, pelas elites e por populares (escravos e livres). ${ }^{7}$ Inúmeros e distintos sentimentos poderiam estar envolvidos na eleição

\footnotetext{
${ }^{7}$ Sem intenção exaustiva, e além dos outros estudos citados ao longo deste artigo, conferir: HAMEISTER, 2006; ANDRADE, 2006.
} 
de padrinhos e na aceitação de ser compadre de outrem, mas também os batismos poderiam ser usados estrategicamente por escravos na freguesia de Albuquerque. E quando falo de estratégia, entendo que a seleção ou a aceitação de uma pessoa e não outra para ser compadre/comadre está relacionada a uma racionalidade empregada para atingir um ou vários objetivos previamente traçados, que poderiam ser imediatos e/ou em médio e longo prazos. O compadrio, como um efeito do sacramento do batismo, é aqui entendido como elemento importante na constituição e/ou no reforço de laços de sociabilidade na sociedade escravista.

Os batismos realizados em Albuquerque foram registrados em livros, como previam as orientaçôes católicas vigentes desde a Contrarreforma (século XVI), com vistas a conhecer quais eram os membros da Igreja, e a constar o parentesco espiritual contraído e a idade dos batizados (MARCÍLIO, 2004, p. 14). Na freguesia, geralmente, os assentos de filhos de escravos continham: a data da celebração; o nome e a idade ou a data de nascimento do batizando; o nome dos pais ou apenas da mãe, em caso de filho natural; a origem ou a cor dos pais; os nomes dos padrinhos e dos proprietários acompanhados de seus estatutos sociais; o local da cerimônia e a assinatura e/ou nome do pároco responsável. Em determinados casos, foram citadas a cor ou a categoria de miscigenaçáo do batizando.

As informações sobre o batismo e o compadrio de escravos em Albuquerque foram obtidas dos dois primeiros livros que parecem ser os únicos livros de batismo da freguesia. Apenas o primeiro deles (1836-1860) foi dividido, com a parte inicial destinada aos livres e a segunda, aos escravos. O segundo livro (1853-1862) foi reservado para registro de livres. Contudo, inseriram-se assentos de filhos de mãe e pai escravos e de pai escravo e mãe livre, e de filho de escravo libertado no ato do batismo (LIVROS DE ASSENTOS DE BATISMOS, 1853-1862 e 1836-1860).

Cabe frisar a relevância da historicidade desses livros porque, além do seu valor para a pesquisa histórica, eles resistiram à ação do tempo e à ocupação paraguaia na região, a partir de dezembro de 1864. Possivelmente, o pároco responsável pela guarda os transportou quando fugiu para outra parte da província de Mato Grosso, quando ficou sabendo das investidas das tropas de Solano Lopez. Além disso, esses livros abarcam o período de existência da freguesia de Albuquerque, com dados que contabilizam os batismos até alguns anos antes da Guerra. Após o conflito, em 1870, a freguesia foi extinta e sua área de jurisdição incorporada à freguesia de Santa Cruz de Corumbá, com sede nessa última localidade, e não mais em Albuquerque. Atualmente, Albuquerque é um distrito do município de Corumbá. A junção das freguesias esteve vinculada ao destaque e importância dessa última localidade no período pós-Guerra do Paraguai contra a Tríplice Aliança, com a reabertura da navegação a vapor no rio Paraguai (SENA, 2017b, p. 46-47).

De 1836 a 1862 ocorreram 1.062 celebraçóes batismais em Albuquerque, sendo 985 de livres (brancos, afrodescendentes, mestiços e indígenas) e 77 de pessoas escravas. Para esta análise separei do primeiro livro 70 registros de batismo na seção de escravos. Destes, qua- 
tro pertenciam à freguesia de Miranda, e não foram computados na análise. Há mais cinco registros na seção de livres. ${ }^{8}$ Do segundo livro, destinado ao registro de livres, estấo seis assentos de filhos de escravos. Desse modo, para este estudo foram analisados 77 registros de filhos de escravos e mais 17 registros em que escravos foram padrinhos de livres.

Apesar do reduzido número de assentos, eles informam sobre o comportamento de pessoas escravizadas em uma área distante dos centros de governos imperial e provincial, condicionadas aos ciclos alagadiços do Pantanal e em zona de fronteira litigiosa e incerta. Os registros também ilustram sobre as atitudes desse grupo social perante um sacramento católico, bem como as estratégias que escravizados buscaram para (sobre)viver ou atingir determinados objetivos no regime escravocrata. As formas de sociabilidade são também possíveis de ser compreendidas, pois os escravizados se relacionaram com pessoas de diferentes segmentos sociais que integravam uma freguesia com expressiva população indígena e mestiça, mas também com a presença de brancos e negros.

Os batismos de escravos ocorriam frequentemente nos momentos iniciais da vida. Entre os batizandos, 61 receberam o sacramento até o primeiro ano de idade, enquanto que 11 foram batizados após essa faixa etária, e cinco não tiveram as idades mencionadas. Os pais, africanos ou afrodescendentes, apresentaram seus filhos no ato do batismo com nomes comuns no idioma português, tais como: João, Antônio, Lusia, Maria, Benedita, Lucio, Miguel etc. Em alguns casos, os nomes eram escolhidos para homenagear o padrinho ou a madrinha, como aconteceu com Lucinda, filha da crioula Luciana, escrava de Joaquim José Gomes da Silva, que foi apadrinhada por Lucinda Maria da Lapa e Antonio Francisco Bueno.

A quantidade anual de batismos de escravos foi pequena, como demonstra o gráfico a seguir:

Gráfico 1 - Batismo escravo por ano, freguesia de Albuquerque (1836-1862)

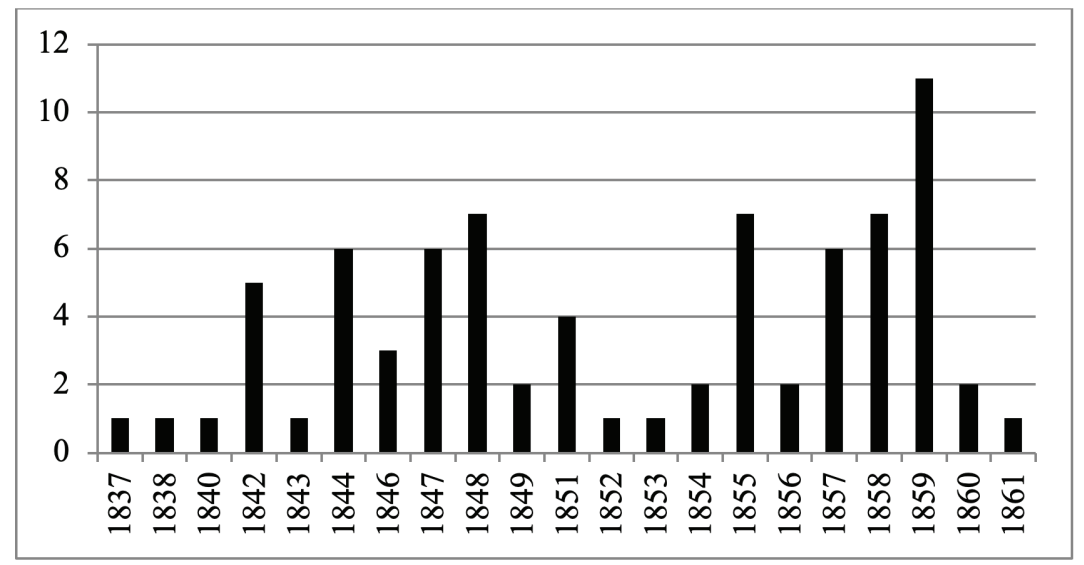

Fontes: LIVROS DE ASSENTOS DE BATISMOS (1836-1860) e (1853-1862).

\footnotetext{
${ }^{8} \mathrm{Na}$ seção de escravos também existe um registro de pessoa livre.
} 
Não há homogeneidade no total anual de batismos. Geralmente aconteciam não mais que dois batismos por ano e, em alguns casos, como em 1845 e 1850, por exemplo, não houve celebraçôes. Em meados dos anos 1840, o número de batismos cresceu e destoou dos anos anteriores, provável efeito do surgimento de novas propriedades rurais e do pequeno aumento de escravos. Outra elevação do número de batizados decorreu após a abertura da navegação a vapor no rio Paraguai, quando a região recebeu mais pessoas que possivelmente possuíam escravas que deram à luz ou batizaram seus filhos na área de jurisdição da freguesia. Entretanto, no geral, o número de batizados foi reduzido, assim como era diminuto o total da populaçáo escravizada na freguesia. A pequena quantidade de batizandos pode ser percebida também na não utilização total da seção destinada ao registro de escravos. Como a metade do $1^{\circ}$ Livro de Batismo foi reservada para o registro de escravos, as anotaçôes chegaram apenas até o verso do fólio 76, do total das 134 folhas que compunham o livro.

A maioria das celebraçôes ocorreu na sede em Albuquerque. As outras foram em propriedades rurais e demais espacialidades que pertenciam à freguesia. Era comum encontrar, nas propriedades rurais, oratório privado com imagens, figuras e outras ornamentaçôes relacionadas ao Catolicismo, onde eram realizados batismos e matrimônios. O Catolicismo, religiáo oficial do Império, fez parte da vida dos proprietários rurais e moradores da freguesia que logo buscavam inserir a sua escravaria na conversão ou no reforço da religiosidade católica.

Quadro 1 - Proprietários com mais escravos batizados, freguesia de Albuquerque (1836-1862)

\begin{tabular}{|c|c|}
\hline Proprietário & No de escravaria batizada \\
\hline Alexandrina de Sousa Vas Canavarro & 2 \\
\hline Antonio Maria Coelho & 2 \\
\hline Jacinto Pompeo de Camargo & 3 \\
\hline Joaquim Francisco de Arruda & 5 \\
\hline Joaquim José de Pinho & 4 \\
\hline Joaquim José Gomes da Silva e D. Maria da Glória & 11 \\
\hline José Estanislao de Pinho & 2 \\
\hline José Rufo de Pinho e D. Ana Joaquina da [Costa] Pinho & 9 \\
\hline Thomé Ribeiro de Magalhães & 4 \\
\hline José Nicolau Rodrigues e D. Maria Bernarda dos Santos & 9 \\
\hline
\end{tabular}

Obs.: Não foram contabilizados os filhos de escravos que nasceram livres ou ficaram livres antes do batismo. Fontes: LIVROS DE ASSENTOS DE BATISMOS (1836-1860) e (1853-1862).

Os proprietários que mais tiveram escravaria batizada foram, respectivamente, Joaquim José Gomes da Silva9 e D. Maria da Glória com 11 escravos, um deles adulto; Ana Joaquina da Costa Pinho e José Rufo de Pinho, que por muitos anos foi o comandante do Quartel em

\footnotetext{
${ }^{9}$ Joaquim José Gomes da Silva recebeu título nobiliárquico de Barão de Vila Maria por decreto do Governo Imperial de 21/6/1862.
} 
Albuquerque (posição militar mais elevada na freguesia); e o casal Capitão José Nicolau Rodrigues (ocupou o cargo juiz de paz, autoridade do judiciário na freguesia) e D. Maria Bernarda dos Santos. Os proprietários listados, que integravam as elites locais, tinham, juntos, $51(69 \%)$ dos 73 filhos de escravos que foram batizados como escravos no ato do batismo. Portanto, a maioria da escravaria que nasceu e que foi batizada estava concentrada nas mãos de poucos proprietários; os demais estavam distribuídos entre outras pessoas da localidade. As fontes paroquiais não são as mais propícias para contabilizar a posse de escravos, como se sucede com os inventários post mortem e com as listas nominativas de habitantes, mas podem dar uma boa representação do cenário, como vimos no Quadro 1.

Para determinados senhores, era importante a reprodução endógena da comunidade escrava, pela perspectiva de aumento ou reposição de mão de obra, pois a compra de cativos nos mercados externos à freguesia era pequena por boa parte dos proprietários. O reduzido número de escravos por propriedade foi uma característica em áreas voltadas à subsistência ou ao abastecimento interno, em que a capacidade de compra de cativos em idade produtiva era menor (MACHADO, 2006, p. 49-77).

Alguns dos proprietários aprovavam o casamento entre seus escravos. No período anterior à Guerra, dos 21 matrimônios de escravizados efetivados na freguesia, sendo 17 casais escravos e quatro mistos (esposos cativos e esposas livres), Joaquim José Gomes da Silva foi o proprietário que mais teve escravos que contraíram matrimônio (seis casais de escravos e dois mistos), seguido pelo Capitão José Nicolau Rodrigues (LIVRO DE ASSENTOS DE MATRIMÔNIOS, 1836-1860). Não por acaso, ambos os proprietários possuíram a maior quantia de filhos de escravos batizados, como destacado anteriormente.

Mais frequente que o matrimônio de cativos, o batismo de filho de escravos foi um procedimento comum na freguesia. Acredito que a maioria da escravaria teve seus filhos levados a receber o sacramento do batismo, o que garantia a inserção do batizando no "reino do céu" (como acreditava a maioria dos senhores) e na sociedade da freguesia. Deixar de ser pagão traria benefícios celestiais e terrenos, dentre os quais a utilização estratégica do sacramento para fins que visassem à aproximação ou à intensificação de relaçóes entre indivíduos de uma mesma ou de distinta parcela social.

Nos assentos de batismos de escravos, constavam apenas um padrinho e uma madrinha que, segundo a orientação católica, seriam selecionados pelos pais ou pessoas responsáveis pela criança. Os padres estavam proibidos de aceitar outros padrinhos diversos dos indicados e realizar batismo se os padrinhos fossem pagáos, infiéis, hereges, excomungados, interditos, surdos, mudos e se ignorassem os princípios da fé católica (CONSTITUIÇÓES, 2011, Título XVIII, p. 26).

A análise das fontes paroquiais levou ao entendimento de que escravos da freguesia de $\mathrm{Al}-$ buquerque possuíam, embora submetidos a estratégias de controle dos senhores, determinadas preferências de escolha de suas vidas, como eleger os padrinhos de seus filhos e criar/manter la- 
ços parentais e sociais. Partindo desse princípio, considero que os senhores não designavam os padrinhos aos filhos dos escravos, mas que essa era uma opção deles. Os estudos sobre batismo e compadrio citados aqui apontam que essa era uma situaçáo comum na sociedade escravista, assim como o uso estratégico do sacramento para atingir variados benefícios.

Em Albuquerque, os filhos de escravos foram classificados nos assentos como provenientes de uniôes legítimas ou ilegítimas. Eram legítimos os filhos de pais unidos via matrimônio, ou seja, fruto de um laço reconhecido pela Igreja, pelo Estado e pela sociedade. Os ilegítimos eram filhos de pais sem vínculo matrimonial, que despossuíam o consentimento da Igreja. Nos assentos, o filho ilegítimo, também denominado de "natural", aparecia apenas com o nome da mãe.

A ilegitimidade escrava foi elevada na freguesia, porque mais de $63 \%$ dos batizandos resultaram de cópulas entre pessoas náo casadas, enquanto $28,5 \%$ foram provenientes de uniôes legítimas. Em 8,5\% dos batizandos, não apareceu tal informação. No conjunto da populaçáo da freguesia, o percentual de ilegitimidade antes de 1864 foi significativo, pois mais da metade $(51,8 \%)$ dos batizandos era de naturais, situação que não diferenciava de outras partes do Brasi ${ }^{10}$ e, particularmente, da província. Na paróquia Senhor Bom Jesus de Cuiabá, por exemplo, 43,5\% dos que receberam batismo eram naturais. Maria Peraro, ao comparar esse valor com o percentual de ilegitimidade em outras localidades, constatou que Cuiabá possuía índice maior que nas paróquias de Curitiba, São Paulo, Sorocaba (SP), São Cristóvão (RJ), entre outras (PERARO, 2001, p. 121). A ilegitimidade foi comum não apenas entre os escravos, pois foi constante entre os livres, principalmente os pobres, e não totalmente inexistente entre pessoas das elites. Essa configuração propicia aventar que, na freguesia de Albuquerque, a maioria das famílias escravas era matrifocal, ou seja, formada de mães solteiras e seus rebentos, assim como os parentes a elas unidos.

No total de batizandos naturais ou legítimos, a maioria teve padrinhos livres, porque apenas $16,8 \%$ foram batizados por padrinho e/ou madrinha de igual condiçáo. A preferência da maioria das mães escravas era por padrinhos livres, fossem elas casadas ou solteiras. Essa característica foi igualmente comum em outras regiôes que possuíam pequena e média escravaria. ${ }^{11}$ Em contrapartida, em freguesias com predomínio de escravaria extensa, o percentual de compadrio entre escravos foi mais expressivo. Ana Rios identificou que, em Paraíba do Sul, nas escravarias maiores, a busca era principalmente por padrinhos escravos; nas demais, predominava a predileção por livres (RIOS, 1990). José Roberto Góes explicitou que, nesses casos, o compadrio era uma maneira de inserir os africanos recém-chegados e de proporcionar modos de socialização para formar uma comunidade escrava (GÓES, 1993). Entretanto, para Slenes, essa inserção não estava ausente de um aspecto hierárquico que

\footnotetext{
${ }^{10}$ Conferir: ANDRADE, 2006; BRÜGGER, 2004, p. 1-21; MACHADO, 2006.

${ }^{11}$ Diante de outros estudos sobre o tema, indico: BRÜGGER, 2004; ANDRADE, 2006.
} 
existia no compadrio entre cativos, no qual os escravos com mão de obra especializada ou doméstica apadrinhavam mais que os de lavoura (SLENES, 1997).

Renato Venâncio caminhou na mesma linha de reflexáo. Para ele, o estudo do compadrio desvela relaçôes complexas, pois algumas pesquisas indicam que, em regiôes periféricas ao sistema escravista, que recebiam poucos africanos e com produção voltada à subsistência e mercado interno, a maioria dos compadres de cativos era de pessoas livres. Em compensação, áreas com expansão econômica e com grande entrada de escravos africanos teriam intenso compadrio entre escravos (VENÂNCIO, 2003, p. 598-607).

Como a maioria da população de Albuquerque era livre, é compreensível que, proporcionalmente, escravos tivessem mais padrinhos livres que de igual condição, dada a maior oferta de opçóes de padrinhos livres. Além disso, o batismo foi empregado por escravos para se aproximarem ou intensificarem vínculos com livres, fossem eles pobres ou de posiçóes mais elevadas, visando a alcançar distintas vantagens materiais, relacionais e/ou simbólicas.

O compadrio com homens das elites (15 no total, Gráfico 2) foi menor que com outros livres. Os homens das elites na regiáo de fronteira geralmente portavam patente militar do Exército ou da Guarda Nacional; muitos também eram proprietários rurais, com negócios e escravos na região. Com exceção de dois desses indivíduos (padrinhos duas e três vezes, respectivamente), os oficiais militares foram padrinhos apenas uma vez, não sendo frequente o apadrinhamento de escravos por um mesmo homem da elite local. Os padrinhos nessas condiçóes provavelmente compunham o círculo relacional dos senhores, contribuindo para que os escravos estreitassem laços com outros proprietários/oficiais militares.

Gráfico 2 - Oficiais militares que batizaram filhos de escravas, freguesia de Albuquerque (1836-1862)

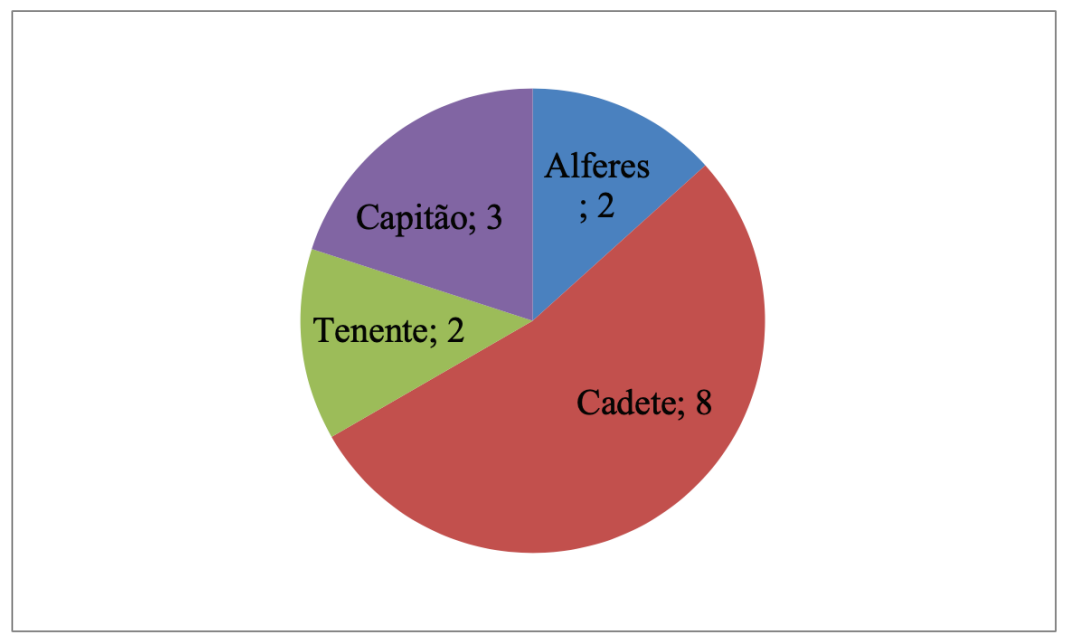

Fonte: LIVROS DE ASSENTOS DE BATISMOS (1836-1860) e (1853-1862) 
Incomum em Albuquerque foi o apadrinhamento de cativos pelos seus respectivos senhores. Circunstância análoga foi constatada em outras regiôes de diferentes dimensôes no quantitativo de escravos (GUDEMAN e SCHWARTZ, 1988; VASCONCELLOS, 1997, p. 7-27; GÓES, 1993). Brügger apurou igualmente um reduzido número de senhores batizando seus escravos em São João del Rei, mas chamou a atenção para outros membros da família senhorial, como os filhos dos proprietários, que desempenharam o papel de ligar ambas as famílias e procurar manter presentes valores patriarcais (BRÜGGER, 2004). Situaçôes correlatas ocorreram em Albuquerque, visto que, apesar de Joaquim José Gomes da Silva ter batizado somente um dos seus escravos adultos, um africano possivelmente recém-adquirido e ingresso na comunidade escrava das Piraputangas, outra criança filha de sua escrava foi apadrinhada pelos seus dois filhos (Firmino Gomes da Silva e Marcolina Gomes). $\mathrm{O}$ apadrinhamento de escravos "por parentes do senhor poder-se-ia acrescentar que, da perspectiva do pai ou da mãe da criança, seria estratégico ter como aliado alguém que, embora não pertencesse à casa do senhor, era seu parente, portanto suficientemente próximo para poder interferir em caso de conflitos" (MACHADO, 2006, p. 73). Esses casos vão ao encontro da ideia defendida por Katia Mattoso, de que o compadrio de escravos e livres seguia a regra da sociedade brasileira referente à família extensa, porque os laços conectavam, além dos padrinhos e afilhados, as famílias de ambas as partes (MATTOSO, 2003).

Eleger padrinhos livres (abastados ou pobres) seria estratégico para alguns escravos estreitarem ou construírem laços de amizades, quando não, para obter algum benefício/ proteçẫo. Esse laço "significava privilégios e deveres de ambas as partes, os quais eram reconhecidos através da obediência, fidelidade e reverência do afilhado, em contrapartida às múltiplas responsabilidades dos padrinhos" (VENÂNCIO; SOUSA; PEREIRA, 2006, p. 276). Raymundo, filho de Josefa Africana, escrava de Ricardo da Costa Leite, por exemplo, antes de ir à Pia Batismal, em 1854, com 14 dias de vida, obteve a liberdade comprada pelo padrinho Joaquim José Gomes da Silva, que deu ao "seu senhor a quantia de cem mil reis", e por isso foi batizado como uma criança livre. A madrinha da criança foi Maria Pardo Belém, uma mulher provavelmente livre pobre e mestiça (LIVRO DE ASSENTOS DE BATISMOS, 1853-1862).

Cacilda Machado identificou que, na freguesia de São José dos Pinhais (PR), no final do século XVIII e início do XIX, escravos se valiam do parentesco espiritual tanto para obter/garantir amparo para si e para seus filhos, ao se ligarem a membros das elites, como também se tornavam compadres de outros escravos e livres pobres para reforçar laços de amizade e aliança com pessoas da comunidade da qual faziam parte. Além disso, a autora localizou indícios da existência de laços sociais e afetivos entre membros das elites e escravos (MACHADO, 2006).

Essas relaçôes de compadrio poderiam reforçar as redes sociais, consanguíneas e afetivas com pessoas livres (pobres e abastadas) e com outros escravos. O compadrio entre escravos 
também não deixava de proporcionar algumas vantagens, ainda que fossem inicialmente estimuladas por situaçóes de amizade ou de laços familiares entre as partes envolvidas.

Quadro 2 - Compadrio e apadrinhamento entre escravos, freguesia de Albuquerque (1836-1862)

\begin{tabular}{|c|c|c|c|}
\hline $\begin{array}{c}\text { Compadres escravos de um mesmo } \\
\text { proprietário }\end{array}$ & \multicolumn{2}{|c|}{$\begin{array}{c}\text { Compadres escravos de proprietários } \\
\text { diferentes }\end{array}$} \\
\hline Padrinho & Madrinha & Padrinho & Madrinha \\
\hline 8 & 6 & 4 & 7 \\
\hline
\end{tabular}

Fontes: LIVROS DE ASSENTOS DE BATISMOS (1836-1860) e (1853-1862)

Oito padrinhos e seis madrinhas escravizados pertenciam ao mesmo proprietário do batizando e/ou de sua mãe, enquanto quatro padrinhos e sete madrinhas eram de proprietários distintos. Os dados mostram a ocorrência de compadrio e apadrinhamento entre escravos de proprietários diferentes, sinal de que havia convivência e proximidade entre eles. Além da existência de pequenas comunidades negras, livres e libertos nos limites de algumas instalações rurais, é possível imaginar a presença de comunidade maior desse tipo na área da freguesia que extrapolava os limites das propriedades.

O compadrio foi mais frequente entre escravos de alguns proprietários e não de outros. A análise horizontal das informaçóes demonstrou que escravos de determinados senhores não estiveram ligados por laços construídos ou reforçados pelo batismo com escravos de outros proprietários. Os de Joaquim José Gomes da Silva, por exemplo, não apadrinharam e não foram batizados por escravos de outros proprietários. Quatro escravizados desse senhor tiveram padrinhos de igual condição, mas todos eles também pertencentes a Gomes da Silva. É provável que cativos desse proprietário, tentando intensificar os laços sociais com outros escravos do mesmo senhor, preferiram eleger padrinhos daquele círculo. Não descarto a possibilidade de que a quantidade de escravos desse proprietário fosse maior, porque ele era um dos que mais possuíram escravos batizados; por isso também a provável desnecessidade de buscar padrinhos fora da propriedade. Apesar disso, esse aspecto não é cabível para todos os escravos da região, já que os de Joaquim Francisco de Arruda foram apadrinhados por escravos do Tenente João Serqueira de Caldas, de Rosa Maria da Conceição, e do Capitão José Rufo de Pinho.

Padrinhos escravos de outra propriedade talvez pertencessem a proprietários vizinhos e/ ou que mantinham vínculos relacionais com o senhor dos pais do batizando. A proximidade permitia a convivência entre os padrinhos de elite e pais cativos e mesmo entre os próprios escravizados de diferentes senhores. Os vínculos entre o Cadete José Estanislao de Pinho e o Capitão José Nicolau Rodrigues concorreram para a construção ou o fortalecimento de relações entre seus escravos. A crioula Joana, de José Estanislao, deu seus filhos Januario e Honorato para serem batizados por José e Rosa, escravos de José Nicolau. Os batismos se de- 
ram respectivamente em 1844 e 1848, sinalizando anos de relaçóes entre esses escravizados, que pertenciam a proprietários diferentes.

Os vínculos familiares também oportunizavam ligaçôes entre escravos de parentes. Foi dessa forma que Ignes Crioula, do Capitão Joaquim José de Pinho, se aproximou de Joaquina Crioula, escrava do irmão de Joaquim Pinho, o Capitão José Rufo de Pinho. O laço entre ambas foi legitimado ou reforçado em 1846 quando Cozisia, filha de Ignes, foi apadrinhada por Joaquina (LIVRO DE ASSENTOS DE BATISMOS, 1836-1860).

Os contatos com escravos e livres de outras áreas aconteciam quando se deslocavam para a realização de atividades variadas e/ou para acompanhar seus senhores em viagens de negócios, relativas a questôes familiares, visitas a amigos e parentes, participação em festividades etc. Esses momentos serviam para que escravos e livres separados por distâncias se conhecessem e convivessem com mais frequência ou esporadicamente, favorecendo a construção ou o reforço de laços de proximidade.

O compadrio entre escravos verificava-se principalmente quando o batizando era filho natural/ilegítimo (11 nessa condição e dois legítimos). Como havia mais mães escravas solteiras que casadas, explica-se a diferença numérica das solteiras que tinham compadrio entre iguais, em comparação com os casais de escravos. Todavia, estes últimos usualmente buscavam compadrio entre os livres. Esses casais conseguiriam algumas vantagens e estabilidades nem sempre estendidas à escravaria solteira. Como observou Slenes (1999), a constituição de famílias poderia trazer vantagens para os escravos, como obter moradia separada, alguma autonomia de ordem religiosa, cultural, social etc. Escravos nessa condição talvez não vissem benefícios em estreitar laços com outros escravizados ao darem seus filhos para serem apadrinhados por iguais. Porém, buscavam proximidade com livres. Essa afirmação é reforçada pelo fato de que uma das duas crianças de pais casados teve padrinho livre e madrinha escrava. Ou seja, apenas um batizando legítimo teve padrinho e madrinha escravos.

Conciliar padrinho livre e madrinha escrava ou vice-versa também foi uma prática adotada por mães solteiras, mas numericamente menor, pois a preferência, quando envolvia iguais, era buscar padrinho e madrinha escravos. Uma evidência de como o batismo foi empregado por casais escravos para ampliarem vínculos relacionais com livres e de como o compadrio entre escravos, embora menor no total das celebraçóes, foi buscado principalmente por escravas solteiras. Estas talvez pretendessem garantir proteção para seus filhos na comunidade à qual pertenciam, se porventura ficassem ausentes. ${ }^{12}$

\section{Padrinhos e compadres de escravos}

Em um exercício de compreensão das formas de utilização do sacramento católico por cativos, convém aprofundar em alguns casos de compadrio, que também servem para

\footnotetext{
${ }^{12}$ Pouquíssimos foram os casos de apadrinhamento por padres e santos (dois ao todo).
} 
ilustrar características da freguesia. A inexistência ou a dificuldade de localizar fontes complementares (como inventários post mortem, listas nominativas de habitantes, testamentos etc.) referentes à região no período anterior à Guerra do Paraguai contra a Tríplice Aliança - pois parte da documentação se perdeu ou se encontra em acervos de Cuiabá (que foi capital da província de Mato Grosso), nem sempre organizados e catalogados são obstáculos que desafiam análises horizontais detalhadas a partir do cruzamento de informaçôes sobre escravos e seus respectivos proprietários. $\mathrm{Na}$ impossibilidade de acessar determinadas fontes, o historiador deve recorrer a outros materiais ou às informaçôes disponíveis para fabricar o seu mel, na falta das flores habituais, como enfatizou Febvre (1989). No caso em tela, a documentação paroquial analisada pormenorizadamente, articulada entre si e com outras fontes esparsas, viabiliza enxergar aspectos nem sempre perceptíveis apenas em uma análise quantitativa.

Entre os padrinhos escravos escolhidos estava José de Guiné, casado com Rosa, ambos pertencentes ao Capitão José Nicolau Rodrigues e Dona Maria Bernarda dos Santos. José e Rosa apadrinharam filhos de escravos dos seus senhores e de mais proprietários, assim como de mães casadas e solteiras, sendo o casal que mais batizou filhos de escravas (quatro, no total).

José também batizou Aniceta, em 1852, filha legítima de Manoel Benguela e Sebastiana Crioula (escravos da sua proprietária viúva Dona Maria Bernarda dos Santos), cuja madrinha foi Dona Antonia Dijacio de Ramos. Esses pais tiveram escolhas diferentes dos demais escravos compadres de José, porque não apenas convidaram um escravo antigo da propriedade dos seus senhores, como uma mulher livre e das elites para batizar a sua filha. Eles desejavam construir ou reforçar relaçôes entre os livres e os escravos. Neste último, contava-se também com a influência e outros contatos de compadrio feitos pelo escravo José.

José estava na freguesia desde o princípio da ocupação da região por criadores de gado (anos 1830), como eram seus proprietários. Ele e a esposa tiveram e batizaram seu filho em 1837, apadrinhado por Pedro Luis de Amorim e Antonia Joaquina do Rosario, pessoas livres da freguesia. O casal constituía, portanto, propriedade antiga de José Nicolau Rodrigues e de D. Maria Bernarda dos Santos, e teve postura distinta dos seus compadres escravizados, ao convidarem pessoas livres para apadrinharem seu filho, talvez tentando firmar ou consolidar, naquele momento, relaçóes no espaço social dos livres e não dos escravizados.

Estratégia distinta foi traçada pelo casal Manoel Benguela e Sebastiana Crioula, que pretendiam, como dito, consolidar laços tanto no espaço social dos livres como dos escravos. Essa postura foi reforçada quando, em 1856, convidaram para serem padrinhos de batismo do seu filho Jorge um casal livre, Miguel Machado da Costa e Cacimira Antonia de Sousa. Assim, Manoel e Sebastiana já tinham um apoio na comunidade escrava com a presença do escravo José como compadre e com uma mulher das elites locais. Com o novo filho, viram a oportunidade de conquista ou de reforço do contato entre os livres. 
Manoel Benguela e a esposa não apadrinharam filho de escravas. Os vínculos afetivos com iguais pelo viés do batismo foram (con)firmados no compadrio com o escravo José. Nem todos os escravos da regiáo foram padrinhos. Alguns acabaram escolhidos por terem alguma importância ou representatividade na comunidade escrava de uma dada propriedade ou até da freguesia.

Interessa destacar que os nomes dos casais Manoel Benguela e Sebastiana Crioula e de José de Guiné e Rosa não aparecem como padrinhos na seção de batismo de livres. Para eles, a possibilidade de maior inserçáo entre os livres seria buscar padrinhos livres para seus filhos, como fizeram.

Outros escravos do casal Capitão José Nicolau Rodrigues e D. Maria Bernarda dos Santos exploraram os objetivos que poderiam ser atingidos com o sacramento do batismo, como fez o escravo africano Constantino com sua esposa Lodovina, que batizaram escravos da mesma propriedade e de outros senhores e filhos de pessoas livres ou libertas (LIVRO DE ASSENTOS DE BATISMOS, 1836-1860). Os escravos de José Nicolau e de D. Maria Bernarda procuraram intensificar relaçóes com outros escravos da propriedade onde residiam. Escravas (casadas ou solteiras) também escolheram pessoas livres para batizarem seus filhos. Algumas conciliaram, para um filho, padrinhos escravos, e para os demais, padrinhos livres (abastados ou pobres). Ao escolherem indivíduos de diferentes segmentos sociais, os escravos dessa propriedade procuravam garantir estrategicamente algum tipo de aliança ou proteção imediata, a médio ou longo prazo para seus filhos, além de aproximar ou intensificar diferentes vínculos com seus compadres.

Dadas as informaçôes apresentadas, na fazenda de José Nicolau e D. Maria Bernarda poderia haver escravos que formavam uma pequena comunidade negra que mantinha relaçôes entre si, construída quando começaram a conviver depois que integraram a escravaria daquele local, ampliadas nas vivências cotidianas e fortalecidas, em alguns casos, via apadrinhamento e compadrio.

Esse entendimento é extensivo a outras propriedades rurais da freguesia, como no sítio/engenho das Piraputangas, de Joaquim José Gomes da Silva. Anteriormente à Guerra do Paraguai contra a Tríplice Aliança, esse proprietário foi um dos que mais possuíam cativos na área da freguesia, perfil não alterado após o conflito, quando ele era um dos maiores proprietários de escravos no município de Corumbá. Em 1877, a Junta responsável pela classificação de escravos registrou que a escravaria da herança do Barão contabilizava 19 escravos e 21 escravas (ACMC, 27/9/1877, caixa s/n.). Desde os anos 1840, quando mudou com a sua esposa para a área da freguesia, até 1860, ocorreram matrimônios e batismos dos seus escravos.

O batismo revelou a existência de diferentes vínculos estabelecidos por escravos de Joaquim José Gomes da Silva, seja com pessoas livres, forras e/ou escravizadas que residiam na propriedade. Do mesmo modo que na propriedade de D. Maria Bernarda dos Santos, no 
engenho das Piraputangas existia uma pequena comunidade negra, onde também viviam forros, indígenas e demais livres pobres que se relacionavam e que viam como boas oportunidades o estreitamento ou a intensificação de vínculos de compadrio com seus próximos.

O engenho das Piraputangas era um estabelecimento rural de relevância para o encontro de escravizados, indígenas e demais livres (pobres e das elites locais). Nele se realizavam festas, celebraçóes e atividades de trabalho que ocasionavam a aproximação entre pessoas que não se conheciam ou que se encontravam ali. Joaquim Ferreira Moutinho ${ }^{13}$ forneceu um bom exemplo sobre o tipo de interação que poderia ocorrer. Em 1862, ele foi hospedado por Joaquim José Gomes da Silva (o Barão) e ressaltou que, na festa promovida no engenho, estiveram reunidas as pessoas de mais destaque de Corumbá e Albuquerque e os indígenas da Aldeia do Bom Conselho. Os rapazes formavam uma banda de música e as moças, todas bem vestidas e calçadas, dançavam perfeitamente. Na quadrilha de 16 pares estiveram as indígenas "mais moças e bonitas, e que trajavam melhor". A festa parece ter sido marcante para o cronista, pois a descreveu com nostalgia em seu texto:

Nunca nos recordamos sem saudade da festa que nos ofereceu tão bondoso hóspede, que tão afável se mostrava com todos os seus convidados. Imagine-se uma festa campestre, onde tudo era profusão, em um belíssimo sítio, rodeado de folgazãos e alegres companheiros, tendo ainda, além dos encantos da natureza e de tantos divertimentos a gozar, o estudo e apreciação desses índios que encantavam por sua ótima educação (MOUTINHO, 1869, p. 136).

O discurso civilizador e disciplinador comum no momento (GALETTI, 2012) perpassou as recordaçôes de Moutinho, quando se referiu aos indígenas. Maria da Glória, esposa de Joaquim José Gomes da Silva, também cumpriu papel importante para essa educação "civilizada" e "religiosa", ao batizar boa parte das indígenas que frequentava a propriedade, colaborando para a interação entre os escravos das Piraputangas e os indígenas que regularmente iam "ao seu sítio onde passavam dias" embaixo da hospitalidade da proprietária, que sempre os recebia com afeição (MOUTINHO, 1869, p. 137). A convivência entre escravos, indígenas e outros livres pobres se dava nas fainas compartilhadas, nas visitas frequentes ou casuais, nos momentos de festividade e em outras práticas decorrentes da vivência cotidiana. Dessa proximidade poderiam surgir laços de amizades que seriam fortificados em momentos de batismo de seus respectivos filhos.

No período analisado foram registrados 17 batismos em que escravizados apadrinharam pessoas livres. Os batizandos, do sexo masculino e feminino, eram cabras, pardos e outros mestiços, indígenas (Quiniquináo e Guató), filho natural, sendo alguns de mães indígenas (Guató, Guaná e Guaicurú), filhos legítimos de casais, assim como de pais incógnitos.

\footnotetext{
${ }^{13}$ Comerciante e membro da elite, Moutinho nasceu em Santo Ildefonso, freguesia portuguesa do Conselho do Porto - Portugal. Viveu 18 anos em Cuiabá (1846-1868).
} 
A maioria possuía menos de um ano de idade, o que evidencia serem os padrinhos escolhidos pelos pais ou responsáveis.

As pessoas livres que deram seus filhos para escravos batizarem não foram citadas com pronomes de tratamento e posição de oficialato militar, que geralmente eram aplicados para se referir às das elites locais. Os pais dos batizandos, nesse caso, pertenciam a parcelas mais baixas da população, constituída pelos chamados livres pobres, nas quais estavam inseridos os indígenas. É improvável que as elites tomassem semelhante decisão, já que geralmente procuravam padrinhos de igual ou superior condição socioeconômica.

Assim, pais indígenas e outros livres buscaram vínculos de compadrio com escravizados. A documentação não informa sobre indígenas apadrinhando filhos de escravos. O compadrio entre essas duas parcelas existia quando escravos batizavam filhos de índios. Talvez, alguns escravizados estivessem em melhor posição que indígenas e outros livres pobres em comunidade de determinada propriedade ou da freguesia. Isso colaborava para que estes últimos buscassem compadrio com escravos tentado, possivelmente, encontrar apoio no grupo em que estavam inseridos ou ao qual pretendiam ficar integrados.

Uma análise pormenorizada para discutir os objetivos e atitudes de indígenas e demais livres perante a pia batismal fugiria aos objetivos e limites deste texto. Mas, ficou perceptível a inter-relação que existiam entre estes e forros e escravizados (africanos e afrodescendentes) que habitavam a freguesia.

\section{Considerações finais}

A área pantaneira é historicamente marcada pela presença de grupos indígenas que, gradativamente, foram eliminados, reduzidos, explorados ou "inseridos" na sociedade local. O convívio com brancos e negros proporcionou uma população plural nos elementos fenotípicos, nas formas de viver e de se relacionar. Os vínculos entre indígenas de diferentes etnias e com outros livres e pessoas escravizadas pintaram o cenário daquela freguesia em zona de fronteira. Tais vínculos poderiam se manifestar ou ser construídos também em celebraçôes do Catolicismo.

O batismo proporcionava a construçáo de relaçôes de compadrio que ia além da sua acepçâo religiosa. Com base na análise dos livros de Batismos, os escravos da freguesia de Albuquerque possuíam, mesmo que submetidos a estratégias de controle dos senhores, determinadas preferências de escolha de suas vidas, como eleger padrinhos de seus filhos e criar/ manter laços de parentesco e sociais. A rede de sociabilidade entre diferentes atores sociais (escravos, senhores, pobres e libertos) era (con)firmada pelo compadrio. Em ambientes rurais e na sede da freguesia, existiam comunidades constituídas por livres pobres (libertos, mestiços, indígenas, brancos) e escravizados que possuíam diferentes laços de proximidade entre si, tais como de amizade, de parentesco, amorosos, entre outros. 
Os compadres poderiam se encontrar durante a jornada de trabalho, em momentos festivos ou de visitas, por exemplo. A convivência para alguns era frequente, enquanto para outros era mais esporádica, sem que os vínculos fossem apagados.

A escolha de compadres pelos escravos era principalmente entre os livres. Não obstante, a preferência por livres não foi um padrão na seleção de padrinhos, pois escravos apadrinharam filhos de livres e de outros escravos. As escolhas de padrinhos também poderiam variar de propriedade para propriedade. Enquanto era mais comum escravos de determinados senhores buscarem compadrio com escravos intrapropriedade, para os de outros proprietários houve a possibilidade e/ou necessidade de eleger compadres escravos fora do domínio senhorial. Esses casos servem para elucidar características peculiares à freguesia de Albuquerque, sem tomá-los como um modelo uniforme da localidade.

Assim, o ato do batismo colocava indivíduos de parcelas distintas em uma mesma cerimônia, que simbolizava a proteção do batizando pelos seus padrinhos. Mas, como esclareceu Brugüer (2004, p. 18), “o compadrio não era, por princípio, uma relação entre iguais. Antes, os pais, em geral, procuravam dar seus filhos a apadrinhar por pessoas de algum modo situadas acima deles na hierarquia social". Neste artigo, ao veicular algumas informaçóes sobre o comportamento de escravos no sacramento do batismo, tive a intenção de demonstrar que as estratégias por eles utilizadas circulavam sob uma rede de micropoderes. $\mathrm{O}$ batismo foi um mecanismo empregado para alcançar determinados objetivos, que variavam de escravizado para escravizado e entre os padrinhos escolhidos. A relação espiritual transcendia para o mundo social, onde a proteção dos padrinhos para com os afilhados poderia ganhar suas nuances nem sempre ligadas diretamente ao campo religioso.

A variedade de estudos sobre compadrio e batismo, assim como o aqui exposto, evidencia que o tema é complexo e distante de um padrão homogêneo para pensar o Brasil escravista como um todo. Este artigo intenciona contribuir com o debate, ao propor outra leitura sobre a presença escrava numa freguesia situada em área de fronteira litigiosa, mas integrada à província de Mato Grosso e ocupada pelo Império brasileiro. Ademais, essa região carece de estudos no período em destaque, e essas reflexões acabam sendo, também, uma contribuição para entender as relaçôes de sociabilidade existentes, que envolviam indivíduos de distintas parcelas da sociedade, tomando os escravizados como personagens principais.

Ficou perceptível, nos assentos de batismos, que os escravos tinham alguma autonomia para a escolha dos padrinhos de seus filhos. Ao contrário disso, é preciso dizer que, como expuseram Gudeman e Schwartz (1988), parte da individualidade dos escravos era definida pelo próprio batismo. Os filhos de escravos africanos da freguesia de Albuquerque náo foram batizados com nomes comuns em idiomas africanos, mas cristãos e frequentes no português do Brasil Império. Se, por um lado, o batismo dava alguma brecha para os escravos agirem por suas vontades, por outro, ele também poderia contribuir para a manutenção do sistema escravista, inserindo uma outra religião, condutas e práticas que nem sempre eram assimiladas voluntariamente pelo escravizado. 


\section{Fontes primárias}

ARQUIVO DA CÂMARA MUNICIPAL DE CORUMBÁ (ACMC). Classificação de escravos a serem libertados pelo fundo de emancipação, 27/9/1877. Caixa s/n. Corumbá-MS. CONSTITUIÇÓESS primeiras do Arcebispado da Bahia. Livro Primeiro - feitas e ordenadas pelo ilustríssimo, e reverendíssimo senhor D. Sebastiāo Monteiro da Vide. Brasília: Ed. Senado Federal, 2011.

FALA DO PRESIDENTE da Província à Assembleia Provincial de Mato Grosso. Estevão Ribeiro de Resende, 2 de março de 1839. Disponível em: http://www-apps.crl.edu/brazil/ provincial. Acesso em: mar. 2017.

LIVRO DE ASSENTOS DE BATISMOS de pessoas livres da freguesia de Nossa Senhora da Conceição de Albuquerque (1853-1862). Corumbá/MS: Arquivo da Igreja Matriz Nossa Senhora da Candelária.

LIVRO DE ASSENTOS DE BATISMOS de pessoas livres e escravas da freguesia de Nossa Senhora da Conceição de Albuquerque (1836-1860). Corumbá/MS: Arquivo da Igreja Matriz Nossa Senhora da Candelária.

LIVRO DE ASSENTOS DE MATRIMÔNIOS da freguesia de Nossa Senhora da Conceição de Albuquerque (1836-1860). Corumbá/MS: Arquivo da Igreja Matriz Nossa Senhora da Candelária.

MELGAÇO, Augusto Leverger. Esboço da carta da Provincia de Matto Grosso: em que vão configurados táo somente os rios e pontos principaes e os de que trata a memoria que acompanha o mesmo esboço. Cuiabá, MT: [s.n.], 1860.

RELATÓRIO DO PRESIDENTE de província apresentado à Assembleia Legislativa Provincial de Mato Grosso. Joaquim José de Oliveira, 3 de maio de 1849. Disponível em: http://www-apps.crl.edu/brazil/provincial. Acesso em: mar. 2017.

Referências

ALMEIDA, Elaine Aparecida Cancian de. Cativos nas fazendas pastoris do Sul de Mato Grosso (1825-1888): considerações de pesquisa. História: Debates e Tendências, v. 7, n. 2, p. 119-137, 2008.

ANDRADE, Vitória Fernanda Schettini de. Batismo e apadrinhamento de filhos de mães escravas. São Paulo do Muriaé, 1852-1888. Dissertação (Mestrado em História). Universidade Severino Sombra, Vassouras, 2006. 
BENFICA, Tiago Alinor Hoissa. História e universidade: a institucionalização do campo histórico na Universidade Estadual de Mato Grosso/Universidade Federal de Mato Grosso do Sul (1968-1990). Tese (Doutorado em História), Universidade Federal da Grande Dourados, Dourados, 2016.

BRAZIL, Maria do Carmo. Fronteira negra: dominação, violência e resistência escrava em Mato Grosso 1718-1888. Passo Fundo: Ed. UPF, 2002.

BRÜGGER, Silva Maria Jardim. Compadrio e escravidão: uma análise do apadrinhamento de cativos em São João del Rei, 1730-1850. In: XIV Encontro Nacional de Estudos Populacionais, ABEP, Caxambú-MG, 20-24 set. 2004, p. 1-21.

CORRÊA, Lucia Salsa. Corumbá: um núcleo comercial na fronteira de Mato Grosso (18701920). Corumbá: SLED, 1981.

DORATIOTO, Francisco. Maldita guerra: nova história da Guerra do Paraguai. São Paulo: Companhia das Letras, 2002.

ESSELIN, Paulo Marcos. A pecuária bovina no processo de ocupação e desenvolvimento econômico do pantanal sul-mato-grossense (1830-1910). Dourados: Ed. UFGD, 2011.

FARIA, Sheila de Castro. A colônia em movimento. Rio de Janeiro: Nova Fronteira, 1998.

FEBVRE, Lucien. Combates pela história. 3. ed. Lisboa: Editorial Presença, 1989.

GALETTI, Lylia da Silva Guedes. Sertão, fronteira, Brasil: imagens de Mato Grosso no mapa da civilização. Cuiabá: EdUFMT/Entrelinhas, 2012.

GÓES, José Roberto. O cativeiro imperfeito. Um estudo sobre a escravidão no Rio de Janeiro da primeira metade do século XIX. Vitória (ES): SEJC/SEE, 1993.

GUDEMAN, Stephen; SCHWARTZ, Stuart. Purgando o pecado original: compadrio e batismo de escravos na Bahia no século XVIII. In: REIS, João José (org.). Escravidão e invenção da liberdade: estudos sobre o negro no Brasil. São Paulo: Brasiliense, 1988. p. 33-59.

HAMEISTER, Martha Daisson. Para dar calor à nova povoação: estudo sobre estratégias sociais e familiares a partir dos registros batismais da Vila do Rio Grande (1738-1763). Tese (Doutorado em História Social) - Universidade Federal do Rio de Janeiro, Rio de Janeiro, 2006.

MACHADO, Cacilda. As muitas faces do compadrio de escravos: o caso da freguesia de São José dos Pinhais (PR), na passagem do século XVIII para o XIX. Revista Brasileira de História, São Paulo, v. 26, n. 52, p. 49-77, 2006.

MAIA, Maria Cristina Ferreira. Um marco para a liberdade: Pedra Branca. Cativos na fronteira de Corumbá (BR)/Puerto Suarez (BO). (Século XIX). Dissertação (Mestrado em Estudos Fronteiriços). Universidade Federal de Mato Grosso do Sul, Corumbá, 2014.

MARCÍLIO, Maria Luiza. Os registros paroquiais e a história do Brasil. Varia História, n. 31, p. 13-20, 2004. 
MATTOSO, Kátia M. de Queiros. Ser escravo no Brasil. 3. ed. São Paulo: Brasiliense, 2003. MOURA, Zilda Alves de. Cativos nas terras dos pantanais. Escravidão e resistência no Sul de Mato Grosso. Séculos XVIII e XIX. Passo Fundo: EdUPF, 2008.

MOUTINHO, Joaquim Ferreira. Notícia sobre a província de Matto Grosso. São Paulo: Typographia de Henrique Schoroeder, 1869.

PERARO, Maria Adenir. Bastardos do Império: família e sociedade em Mato Grosso no século XIX. São Paulo: Contexto, 2001.

PINTO, Luiz Maria da Silva. Diccionario da Lingua Brasileira por Luiz Maria da Silva Pinto, natural da Provincia de Goyaz. Na Typographia de Silva, 1832. Disponíveis em: http:// www.brasiliana.usp.br/pt-br/dicionario. Acesso em: jan. 2018.

QUEIROZ, Suely Robles Reis de. Escravidão negra em debate. In: FREITAS, Marcos Cezar (org.). Historiografia brasileira em perspectiva. 6. ed. São Paulo: Contexto, 2005.

RIOS, Ana Maria Lugão. Família e transição: famílias negras em Paraíba do Sul, 18721920. Dissertação (Mestrado em História) - Programa de Pós-Graduação em História, Universidade Federal Fluminense (UFF), Niterói, 1990.

SENA, Divino Marcos de. Entre articulaçóes e conveniências na Câmara Municipalde Corumbá: relações de poder, laços sociais e atuação política no final do Império. Tese (Doutorado em História). Universidade Federal da Grande Dourados, Dourados-MS, 2017b.

SENA, Divino Marcos de. Livres e pobres no centro da América do Sul: um estudo sobre os camaradas (1808-1850). Dourados: Ed. UFGD, 2013.

SENA, Divino Marcos de. Meio século de pesquisa em História Regional: do ISPC ao CPAN/UFMS. Revista GeoPantanal, UFMS/AGB, Corumbá/MS, n. 23, p. 93-109, jul./ dez. 2017a.

SENA, Divino Marcos de. Trabalhadores livres no "Baixo Paraguai" do Império do Brasil. Fronteiras Revista de História, UFGD, v. 12, p. 153-173, 2010.

SILVA, Verone Cristina. Missão, aldeamento e cidade. Os Guaná entre Albuquerque e Cuiabá (1819-1901). Dissertação (Mestrado em História). UFMT, Cuiabá, 2001.

SLENES, Robert W. Senhores e subalternos no Oeste Paulista. In: ALENCASTRO, Luiz Felipe de (org.). História da vida privada no Brasil. Império: a corte e a modernidade nacional. São Paulo: Companhia das Letras, 1997.

SLENES, Robert W. Na senzala, uma flor: esperanças e recordaçôes da família escrava Brasil Sudeste, Século XIX. Rio de Janeiro: Nova Fronteira, 1999.

VASCONCELLOS, Márcia Cristina. Que Deus os abençoe. Batismo de escravos em Angra dos Reis (RJ), no século XIX. História e perspectivas. Revista dos cursos de História. Universidade Federal de Uberlândia, p. 7-27, 1997. 
VENÂNCIO, Renato Pinto. A madrinha ausente: condição feminina no Rio de Janeiro, 1795-1811. In: COSTA, Iraci Del Nero da (org.). Brasil: história econômica e demográfica. São Paulo: IPE/USP, 1986. p. 95-102.

VENÂNCIO, Renato Pinto. Compadrio e rede familiar entre forras de Vila Rica, 17131804. In: V Jornada Setecentista. Curitiba, UFPR: CEDOPE-UFPR, 2003, p. 598-607. Disponível em: http://www.humanas.ufpr.br/portal/cedope/files/2011/12/Compadrioerede-familiar-entre-forras-de-Vila-Rica-1713-1804-Renato-Pinto-Ven\%C3\%A2ncio1. pdf. Acesso em: agosto de 2015.

VENÂNCIO, Renato Pinto; SOUSA, Maria José Ferro de; PEREIRA, Maria Teresa Gonçalves. O compadre governador: redes de compadrio em Vila Rica de fins do século XVIII. Revista Brasileira de História, São Paulo, v. 26, n. 52, p. 273-294, 2006. 